\title{
The Survival of Earthen Architecture in Malian Sahel, Case Study: The Historic City of Djenné
}

\author{
Diakite Siriman, Yanan Wang \\ School of Urban Construction, Yangtze University, Jingzhou, China \\ Email: sissoundiana@gmail.com
}

How to cite this paper: Siriman, D., \& Wang, Y. N. (2021). The Survival of Earthen Architecture in Malian Sahel, Case Study: The Historic City of Djenné. Current Urban Studies, 9, 83-106. https://doi.org/10.4236/cus.2021.91006

Received: January 22, 2021

Accepted: February 26, 2021

Published: March 1, 2021

Copyright (อ 2021 by author(s) and Scientific Research Publishing Inc. This work is licensed under the Creative Commons Attribution International License (CC BY 4.0).

http://creativecommons.org/licenses/by/4.0/ (c) (i) Open Access

\begin{abstract}
Heritage conservation is one of the concerns in public urban governance policies. The Malian Sahel is one of the oldest centers of urban civilization. Listed as a UNESCO World Heritage Site in 1988, Djenné is one of Mali's great tourist destinations. The conservation of the architectural heritage has made tourism the engine for the economy of the city of Djenné. This research aims to assess the impact of the architectural and urban heritage of Djenné on the lives of residents. After zooming in on the advancement of Djenné, this work analyses the deep and complex relationships between urban heritage and the life of the residents. It highlights the advantages and consequences of earthen constructions. It reveals the mysterious character of Djenné. Taking religious beliefs and cultural values into account is essential in any urban project in this mysterious city. The novelty of this work lies in its framework marked by an unprecedented security pressure in the region. Thanks to data collected from the administration, surveys, and interviews with stakeholders, this work carried out elements that indicate the slump currently experienced by the occupants of Djenné. That situation dangerously threatens the conservation of heritage for the future. Finally, all of this should inspire decision-makers and planners to provide mechanisms for building a more dynamic socio-economic life, capable of reorienting and re-adjusting quickly.
\end{abstract}

\section{Keywords}

Architecture, Conservation, City, Heritage, Tourism

\section{Introduction}

The city of Djenné is located in the interior delta of the Niger River, in the 5th administrative region of the Republic of Mali. The hinge between the nomadic world formed by pastoralists (North) and that of sedentary farmers 
(South), Djenné is the flagship of Sudanese architecture. The oldest known city in sub-Saharan Africa, Djenné's center has more than 2000 traditional houses that still survive. Djenné has taken advantage of its rich architecture to develop a tourist economy. In Djenné, heritage conservation mobilizes a whole series of actors and local partners who have vital, cultural, and moral interests. The security crisis in central and northern Mali affected tourism that supported heritage conservation. This crisis justifies the urgent need to assess the impact of this heritage on local life. So, the data can guide the action of the government and partners. What is the impact of the architectural and urban heritage of Djenné on the lives of residents?

In this paper, we present this architectural heritage in its history and then initiate a reflection on its conservation in the special context of insecurity which is already lasting 8 years. After documentary research, we developed questionnaires addressed to the actors. People recruited locally carried out the investigative work. These surveys are supplemented by information obtained during interviews with officials working on the conservation of the architectural heritage and the supervision of tourist activity in Djenné.

\section{The Historical Foundations of Djenné's Architecture}

\subsection{Djenne Djeno}

Djenné Djeno is Djenné's first site. In 1980, an American archaeologist couple, Mr. and Mrs. Mc Intosch (Holder, 2012: p. 6) made important discoveries in Djenné Djeno. In the 3rd century BC, the region would have been founded. According to archaeological findings, the inhabitants knew about iron. Various archaeological pieces have been discovered in Djenné Djeno: pearls, rings, fishing instruments, knives, etc.

The domestication of rice (Oryza glaberrima) would take place in the 3rd century BC in Djenné Djeno.

The discoveries also concerned shards of pottery made with clay from the river. A clay bowl dating from the 3rd century BC was considered the oldest object there.

The case of Djenné Djeno is a contribution of Sudanese architecture to the historical evolution of urbanization in the world just like Jericho (West Bank), Jarmo (Iraq), or çatal Höyük (Turkey)...

The discoveries made by the MacIntosh couple in Djenné Djeno bear witness to the existence of an outline of urban civilization in this part of Malian territory. Indeed, the inhabitants of Djenné Djeno would have built dwellings in the mud. Hand-shaped cylindrical bricks were used to build the city wall. This wall would be $3.7 \mathrm{~m}$ wide. The circumference would be $2 \mathrm{~km}$. The houses were rectangular or round. Djenné Djeno would have counted 10,000 inhabitants in 800 .

From Figure 1, we see that djenné is at the edge of the Niger River. This geographical position favored the urban progress achieved in the region. 


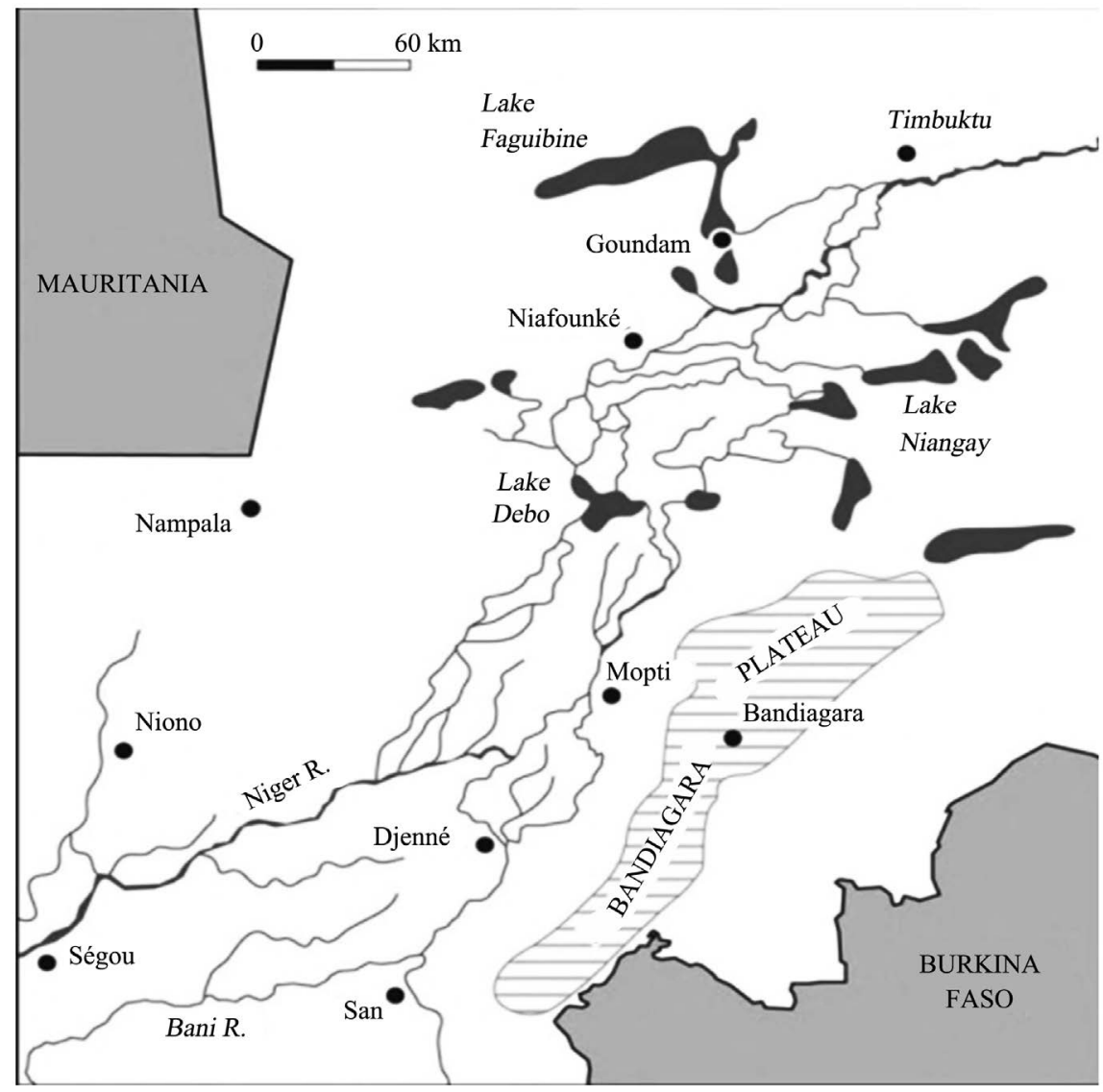

Figure 1. Djenné (Source: Marchand, 2009: p. 3).

\subsection{From Djenne Djeno to Djenné}

From Djenné Djeno, urbanization efforts continued in Djenné, $3 \mathrm{~km}$ from the old site. In the beginning, there was the traditional religion, as evidenced by the human sacrifice (a young girl named Tapama kayantao who became Tapama Djenepo) which would have been at the beginning of the construction of the city.

After the fall of their Empire (Ghana), the Soninke arrived on the banks of the Bani, a tributary of the Niger River. They started building this region which was already inhabited by Bozos fishermen who formed an ethnic group of fishermen. In the Bozo language, "Djenné" means "water genius". The buildings were always broken by the flooding of the river. To enable the building of the city, the oracles announced the sacrifice of a virgin maiden. It was then that Tapama, daughter of Mady Kayantao, 12 years older, was placed between 04 mud walls to be buried alive by clay soil thrown over her. Her name became Tapama Djenepo, which means "Tapama, the martyr of Djenné". Considered as the holy founder of Djenné, the tomb of Tapama djenepo is located at Djenné Kanafa. Venerated by people, it belongs to the UNESCO World Heritage.

In the 13th century, Djenné was integrated into the Mali Empire. In 1280, King Koi Komboro converted to Islam and built his mosque in Djenné. In the 
beginning, Djenné's architecture belongs to Sudan. However, foreign-influenced that architecture. Founded in West Africa, Sudanese architecture is an urban architecture in raw earth. It is mainly in Mali. The constructions have been done with a mixture of clay and straw, rice husks, etc.

This Sudanese architecture is often attributed to the Andalusian architect Abou Ishaq es Sahéli (Cissé, 2008: p. 8) who returned with the emperor Kankou Moussa (empire of Mali) from his famous pilgrimage (visit to Mecca in 1324). In 1325 , he was entrusted by this sovereign with the realization of the mosque that bears his name in Gao. He also built the mosques of Djinguereyber and Timbuktu. All of these mosques are still in Mali. Sudanese architecture has some main characteristic features: intensive use of the land, heights, and buttresses in civil constructions...

This architecture will stand out majestically with colonization. The rectangular bricks and the large windows innovate the constructions. Some constructions still keep at their entrance, the transverse section which aimed to block the passage of the Moorish or Arab slavers who came as riders, in the period of manhunt. The constructions of Djenné had many significants. The ridge above the building wall indicated the family's structure. Thus, a single crest signified the monogamous family. The number of peaks indicated that of wives.

Djenné was conquered by the Songhai Empire in the 15th century. It was seized by the Sultan of Morocco, Ahmed El Mansour in the 16th century. In 1670, Djenné belonged to the Bambara kingdom of Segou before being conquered, in 1819, by Sekou Amadou of the Fulani empire of Macina. Then in 1862, it was occupied by El Hadj Omar TALL before being taken by Louis Archinard in 1893 during the French penetration into Sudan. Jacque Méniaud, aide-de-camp to Lieutenant Colonel Archinard, talking about Djenné, wrote this: "It is the richest and most commercial city that I have seen in Sudan, the one which, for a European, moreover looks like a city, absolutely different from other big black centers which are already familiar to us" (Holder, 2012: p. 9).

\section{Conservation of Architectural Heritage and Tourist Economy in Djenné}

\subsection{Technical and Practical Advantages of Earthen Houses in Djenné}

Half of humanity lives in mud buildings. In France, we have earthen houses, cob, and adobe. In Yemen, we have the eight-story buildings of Shibam "Manhattan of the desert"

Monumental mud-clay architecture is widely expressed in mosques and civil constructions in Mali (Djenné, Mopti, Timbuktu, and Gao). It is still maintained today despite urban growth which has imposed elsewhere (in other cities) much more modern constructions and using sands, gravels, and cement.

"Building earth" means the mixture of water, clay, and a grease remover usually of vegetable origin, used for plasters, mortars, bricks, and solid earth. 
The first known home of the brick invention is the Southern Levant Jericho, Munhata, Aswad...

There are hand-molded bricks and molded bricks in a wooden frame. In Djenné, we mainly have raw bricks, dried in the sun, unlike those baked in the oven.

The survival of this earthen architecture is due to climate, economic, and cultural reasons.

To better understand the mud house's advantages, we sent a questionnaire to 60 owners in Djenné. Their responses are in Table 1.

The percentages contained in Table 1 cannot be combined. The same individual said both different advantages. As we can see in Table 1, the main advantages are economic and climate for populations. They stand out in $90 \%$ of those questioned.

Banco is a material suitable for the Sahel. In Mali, in the dry season, the temperature can exceed $40^{\circ} \mathrm{C}$. Raw earth heats up less quickly than cement. So for thermal comfort, mud construction is suitable for a large part of the population. Access to electricity remains difficult for the poor. We can see this in works that have concerned urbanization in Mali: "it is only in Kayes and Bamako that more than half of households have an electricity connection" (Brunet-Jailly, Charmes, \& Konaté, 2014: p. 558). The report published by the National Institute of Statistics (2018) in February 2018 said that the percentage of households with access to electricity was $24.5 \%$ in $2013 ; 22.9 \%$ in $2014 ; 23.4 \%$ in 2015 and $24 \%$ in 2016. These figures show that electricity coverage is very low for Malian populations.

Banco is available almost everywhere in Mali while cement is still imported. Cement production in Mali is very recent. The mud houses have a thermal regulating effect. In the dry season, it is cold in these houses. In the cold season, they retain heat. This thermal regulation is important in Mali where the population's

Table 1. The advantages of mud houses.

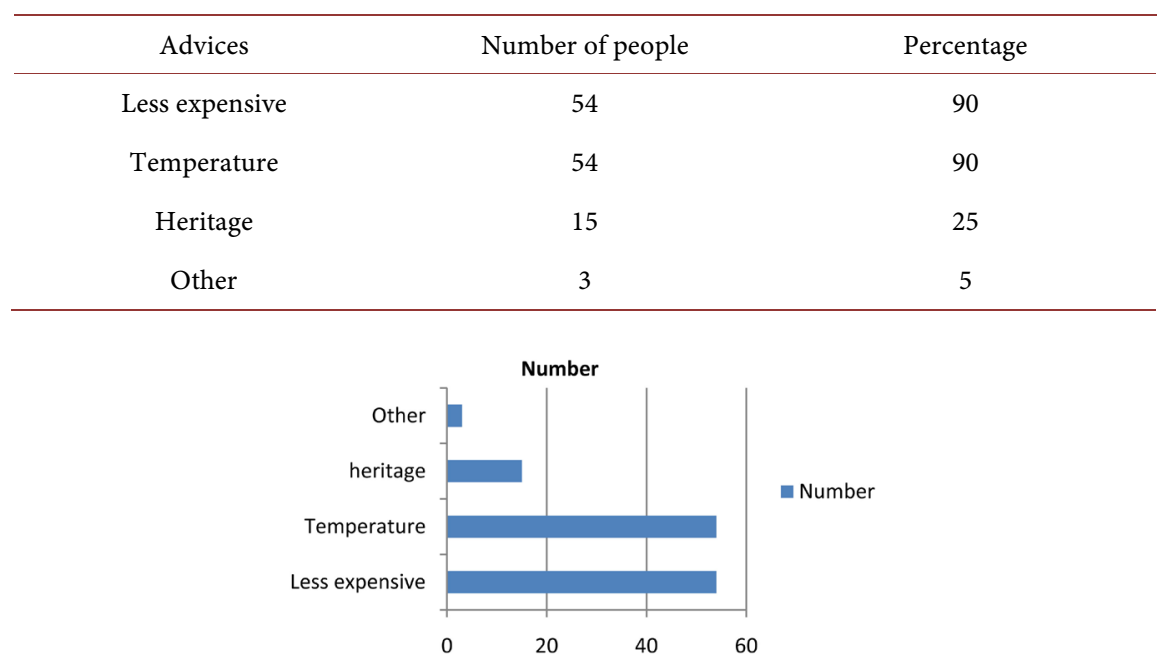

Source: Our own surveys among the inhabitants of Djenné, November 2020. 
needs for electricity are not met. Using the air conditioner remains a luxury for the population.

A land of traditions and culture, 25\% of those interviewed in Djenné are still attached to the values bequeathed by their ancestors. For these people, remaining faithful to the way of the elders is a duty for the younger generations. In some cases, sacrifices and other mystical practices were said to have preceded construction by the ancients. These practices would have the advantage of protecting the family living in the house. Going back on this construction work or changing housing would then expose that family to harm. Also, we have the testimony of the Head of the Cultural Mission: "the ancestors would have ordered the Djennenkés to stay in these houses despite everything. Some ancients have cursed their offspring who would be tempted to build their homes in cement." Djenné is a city where beliefs play a leading role in the population's lives. Any urban or social project that does not take this aspect into account is doomed to failure.

Finally, we have classified under "other" the cases of people who did not want to talk about the issue as well as those who felt that the said houses did not have any advantage. There are indeed people who consider useless these mud houses. To understand these people, let's read the difficulties that the inhabitants of Djenné complain about.

Table 2 shows the ranking of the main difficulties mentioned by the people in our sample. The first difficulty relates to maintenance (70\%). "The upkeep of the heritage requires an investment from the local populations and demands by them to get out of this emergency in which they are plunged and which forces them to manage day by day" (Ouallet, 2007: p. 93). This pass from Ouallet perfectly illustrates the situation in Djenné. As we said above, the maintenance schedule is annual for the majority. People plaster all the constructions with earth to strengthen them. This work takes place in the dry season and most often involves men and children.

Table 2. The difficulties for the occupants of mud houses.

\begin{tabular}{ccc}
\hline Main difficulties & Number & Percentage \\
\hline Maintenance & 42 & 70 \\
Insecurity & 6 & 10 \\
Discomfort & 30 & 50 \\
\hline
\end{tabular}

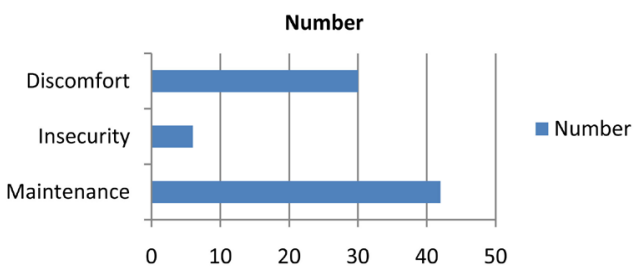

Source: Our own surveys among the inhabitants of Djenné, November 2020. 
If the banco used is a local resource, its access is a bit difficult due to the strong pressure and erosion. There are specific places to find this material for making bricks and renovating houses. The cost of this maintenance work is between 50,000 and 200,000 FCFA (Ouallet, 2007: p. 17). In the dry season, farmers, who usually have no other activities, take care of housekeeping. However, others engage in different activities. Some families let their young people move to the big cities to find out other income-generating activities.

Ten percent (10\%) of those surveyed believe that these mud houses do not offer complete safety despite all the maintenance work. The Sahel knows an irregularity and a poor distribution of the rains. No one controls the rhythm of the rains. Sometimes very heavy rain showers can occur and cause flooding with terrible damage such as collapsing houses. The current water supply system further weakens these houses by digging channels for the passage of pipes to supply families with drinking water. These holes are considered too close to the constructions that they weaken.

Finally, mud houses don't offer all the comforts of modern cement houses. The lack of access to endurance, durability, and all the comforts offered by cement houses is mentioned by $50 \%$ of our interviewees. The latter are certainly tempted by the desire for modernity which offers more comfort and luxury. In the interview with Mr. Moussa DIAKITE, Head of the Cultural Mission of Djenné, he said: "There are difficulties which destabilize the heritage. We have an increase in population. This population needs more space and modernism. In addition, family problems mean that some houses remain in ruins...”. These words from the Head of the Cultural Mission confirm the difficulties experienced by the inhabitants of these houses.

Emphasis is also placed on the disagreements inherent today in family community life, which is a Malian tradition. These misunderstandings then appear as an obstacle to heritage conservation.

Despite all these difficulties, Djenné, was classified as a UNESCO world heritage site, it has a tourist vocation and remains mainly in mud architecture. However, cement construction is starting at a new site indicated by the authorities (east part of the city). This project carries all its risks to urban heritage. The government should bring together all the actors, partners, and technicians to reflect on the future of this architectural heritage in a society in full change and in the context of deep insecurity.

\subsection{The Great Mosque of Djenné}

It is the largest building of mud in Mali. Located in the core of the city, in the Bani alluvial plain, it is considered the greatest achievement of Sudano-Sahelian architecture. But it got Islamic influences throughout history. Its current construction dates from 1907 (Yamoussa \& Joffroy, 2010: p. 18). The first construction, ordered by King Komboro in 1238, had been demolished by the Fulani conqueror Amadou LOBBO who considered that the transformation of the old 
palace into a mosque was too rich. The building was first restored in 1896 before it was demolished. Finally, responding to the request of the marabout Almamy SONFO, the French colonial governor William PONTY agrees to rebuild the old mosque of King KOMBORO. Work began in 1906 and ended in 1907 under the direction of the head of the masons' corporation, Ismaila TRAORE (Photo 1).

The mosque of Djenné has the shape of a square of $76 \mathrm{~m}$ of side. Its height is $20 \mathrm{~m}$. Ninety (90) pillars support the roof. Facing east, the prayer wall ends with 03 large rectangular minarets, each of which contains a staircase. Each minaret forms a cone topped with an ostrich egg. The walls vary from 20 to $40 \mathrm{~cm}$ in thickness. The tallest is the thickest. These walls are made of plastered bricks and mud. Bundles of palm branches embedded in the walls help absorb cracks caused by humidity or temperature changes. The mud walls provide thermal regulation between the high temperature of the day and the coldness of the night. Long gutters made of earth pipes evacuate the rainwater by rejecting it far from the walls. Part of the mosque is covered with a roof. The other is an open-air prayer yard.

Established on a raised platform, this mosque escapes the floods which some sectors of Djenné are confronted with.

The whole community takes part in the maintenance of the mosque which is part of the annual festivities. This maintenance is necessary as rain and temperature variations erode the material used. The pasty plaster, previously prepared and periodically stirred by the children, is used to completely plaster the mosque. In this plastering work, the men climb the bundles of palm trees driven into the walls to reach the walls of the mosque. Women and girls bring water. All the work is directed by the mason's corporation.

Other impressive works of earthen architecture still exist in Mali such as the tomb of the Askias (rulers of the Songhaï Empire) in Gao, the great Friday mosque of Niono (in the 4th administrative region of Mali) or the Komoguel Mosque (in the town of Mopti).

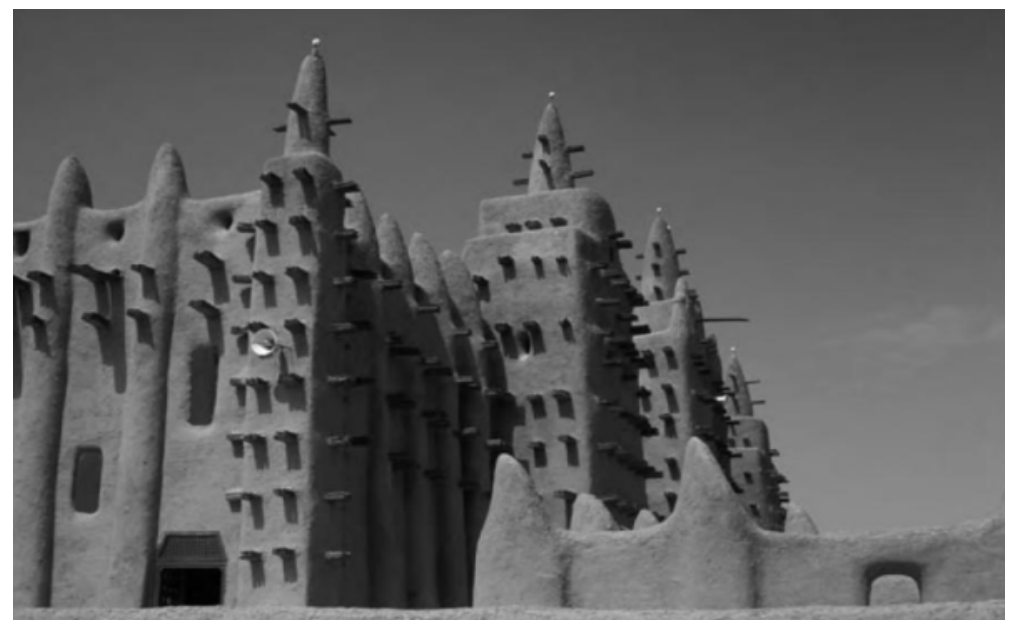

Photo 1. Djenne's great mosque (Source: Marchand, 2009: p. 5). 


\subsection{The Tourist Vocation of Djenné}

Tourism provides $10 \%$ of world GDP. It is one of the vital sectors of the economy in developing countries like Mali. It attracts investment and promotes entrepreneurship while preserving ecosystems and biodiversity and showcasing cultural heritage.

Djenné $\left(13^{\circ} 54^{\prime} 21^{\prime \prime} \mathrm{N} ; 4^{\circ} 33^{\prime} 17^{\prime \prime} \mathrm{W}\right)$ is located in Mali on an island of 88 hectares between two arms of the Bani (a tributary of the Niger River). It experiences a Sahelian-type climate with an average annual rainfall which is between 400 and $600 \mathrm{~mm}$.

In Mali, the National Policy for the City aims to "strengthen local economies to improve the self-financing capacities of cities and fight against underemployment and poverty."

Djenné's past prosperity was due to its position on trade routes and external markets, as well as its productive hinterland. Droughts have reduced production. Climate change and conflicts between stakeholders (farmers, breeders, and fishermen), the lack of land use planning, and poor organization have made activities less productive and living conditions difficult in Djenné. Profound socio-economic transformations have led to a deterioration of the heritage built in mud.

The idea of preserving the world's wealth is old. The International Movement for the Protection of Sites launched the project to rescue the Abu Simbel Temples in Egypt came to fruition by UNESCO in 1959. Other similar initiatives followed elsewhere in Italy, Pakistan, and Indonesia.

In 1977, Mali ratified the Convention of the International Council on Monuments and ICOMOS Sites which dated from 1972 and which established an Intergovernmental World Heritage Committee.

In 1988, the inscription of Djenné and its mosque as a UNESCO World Heritage Site opened up new perspectives. Djenné is a World Heritage town with an urban and architectural unit made entirely of earth. The tourism sector has grown (Loi n $02-016$ du 03 juin 2002 fixant les règles générales de l'urbanisme). Through tourism, the architectural heritage of Djenné promotes the improvement of the living conditions of the local populations.

The Malian government has adopted a whole legal arsenal (laws and other texts) to promote architectural conservation. Among them, we have:

- The law of July 26,1985 , relating to the protection and promotion of the national cultural heritage;

- The ordinance of August 31, 1973, approving the UNESCO international convention concerning the illicit importation and transfer of ownership of the cultural property;

- The decree of December 18, 1992, classifying the old towns of Timbuktu and Djenne;

- The ordinance of August 3, 2001, creating the cultural missions of Bandiagara, Djenne, and Timbuktu, etc. 
UNESCO had asked the states concerned to find ways to properly manage the classified property.

Djenne's cultural mission has to ensure the implementation of the national policy for the preservation and enhancement of cultural heritage at the local level. It works to maintain its heritage. The Management Committee brings together all the sensitivities of the population. The commission is chaired by the Prefect (government representative).

Sometimes, the need for heritage conservation faces the challenges of change. "Too often, recourse to the precepts of sustainable development and heritage, particularly human heritage, rings false in the face of the reality of local deprivation" (Ouallet, 2007).

Regarding architectural conservation in Pakistan, Saima Gulsar and Jean-Pierre Burg wrote: "The main weathering factors affecting the heritage site are therefore both climatic changes and urban pollution” (Gulzar \& Burg, 2018).

Djenné is not immune to the climate changes of the Sahelian strip. Erosion hits hard mud constructions. This is why there is continuous maintenance through plastering. This conservation requires the active and voluntary involvement of local populations.

How to motivate the population for an exercise as laborious as it is meticulous?

Roberta Grignolo told us this: "Squares and streets, buildings and interior spaces built in the 20th century affect our physical and psychological well-being, our social representation and rituals... Therefore, the conservation of the 20th century built heritage concerns not only the experts" (Grignolo, 2018).

In the planning process, the protection of direct self-interest comes to the fore (Namangaya \& Mushi, 2019).

The population ensures the incessant maintenance of individual buildings in the name of the preservation of globally recognized cultural values and that of the public cultural property. In Djenné as elsewhere in Mali (Mopti, Timbuktu), local beliefs admit that any participation in plastering and maintenance of the mosque is a highly blessed act. The plastering sessions are then the subject of large meetings in which people from other cities in the country participate. The prayers and blessings that take place there are in great demand by the faithful. This is the mystery of Djenné. Here are the words of Mr. Moussa DIAKITE, Head of the Cultural Mission: "The people go to the tomb of Tapama Djenepo to pray and their wishes are granted. The water from Nana WANGARA's well is considered as holy water which heals illnesses". These words sufficiently prove the firm belief and the deep attachment of people to the mysteries of Djenné. If we cannot comment on the content of the worship aspect, it is obvious that these meetings facilitate the maintenance of the buildings. We can only agree with Roberta Grignolo.

Despite all this annual maintenance, according to a preliminary study carried out by UNESCO, the great mosque of Djenné could collapse. The maintenance 
process involved applying more "banco", a mixture of mud and rice husks on the walls, and on the roof. More than 500 tons of "banco" overloaded the roof.

In 2004, the Agan KHAN Trust for Culture "AKTC" (Joy, 2016: p. 22), as part of a public-private partnership, began to work for the revitalization of the centers of three cities in Mali. The Aga KHAN Trust carried out the restoration of the large mosques of Djenné and Mopti and that of the Djingareber (Timbuktu). He also designed the surrounding public spaces.

Beyond heritage restoration work, the program aimed to improve the quality of life of the populations by installing new water supply and sanitation systems, paving the streets, educating early childhood, health care, etc (Photo 2).

In 2008, the work began in Djenné. They included the complete restoration of the roof, and the wall structure and the complete replacement of the lighting, ventilation, and sound systems. The local corporation of masons, called "Barey-ton", participated in the work. This involvement of the corporation was aimed at highlighting and strengthening technical capacities through training. The traditional education of masons is based on the transmission of knowledge by apprenticeship. Technologies and secrets are passed down from generation to generation. Any innovation requires the acceptance of peers and the public. Approval is reserved exclusively for more experienced master masons and sometimes posthumously (Marchand, 2009: p. 11). This stage of authority at the corporate level requires many years of practice and training of many disciples in the field.

The archaeological sites of Djenné have also benefited from bilateral Mali/Netherlands cooperation (van Beek, Lemineur, \& Walther, 2007: p. 3). With this cooperation, Djenné's earthen architecture rehabilitation program was launched in 1996. It allowed the restoration of 98 Toucouleurs and Moroccan houses, the training of local masons, and the financing of a system for monitoring archaeological sites by volunteer agents recruited locally. The relationship between these surveillance officers and the local population has been conflicting. The looting continued.

To fight wind erosion, a line of trees had been planted around the Djene Djeno site. Because of anarchic logging and uncontrolled grazing, this cordon has almost disappeared.

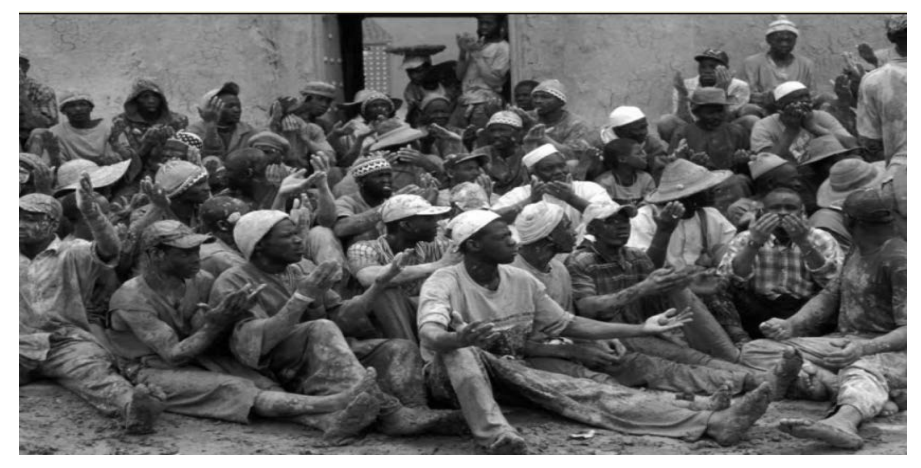

Photo 2. (Source: Marchand, 2009: p. 20). 
Since 1993, Mali has been in the process of decentralization which enshrines the free administration of communities under the conditions provided for by law. The transfer of skills concerns tourism (Decree No. 2015-0353/P-RM of May 8, 2015 setting out the details of the powers transferred from the government to local authorities in the field of tourism). Decentralization presupposes the mobilization of resources at the local level to finance development actions. The community of Djenné is administered by a communal council elected by the local population. Following Malian laws (Law n ${ }^{\circ}$ 96-052 of October 16, 1996 establishing a tourist tax and instruction $\mathrm{n}^{\circ}$ 97-000005/MFC-DNI of July 10, 1997 relating to the collection of the tourist tax), Djenné collects the tourist tax. To know more about the contribution of tourism to municipal development, we were able to interview Mr. Abdrahamane DEMBELE, 2nd Deputy Mayor of Djenné, and in charge of civil status. Here are some of his words: "Thanks to tourism receipts, which exceeded 20 million FCFA per year, we were able to cover many of our expenses. We could build classrooms for schools and kindergartens..."

\subsection{Tourism Accommodation Establishments in Djenné}

A tourist accommodation establishment means any commercial establishment that offers equipped and furnished rooms or apartments for rent either to a daily clientele or to a clientele who makes a specific stay there. It may include a catering service. (Decree No. 01-583/P-RM of December 18, 2001 setting the classification standards for tourist accommodation establishments)

Table 3 shows us that there are currently six opened hotels in Djenné and five temporarily closed establishments.

*The Houber Hotel camp in Djenné:

The beginnings of this Hotel go back to the colonial period (before 1960). They were round huts at that time under the name of the Hotel camp. After renovating this family heritage, it became the Hotel Houber camp in 2000. Located near the town hall, it has 48 rooms and 60 beds. Before the crisis, the hotel had 27 permanent employees with open-ended contracts and agents with fixed-term contracts. Currently, it employs only 5 people. No woman or foreigner works in this hotel at present. The meal is sold at $2000 \mathrm{~F}$ CFA (3.7\$ USD). The room (with suite) is rented at 25,000 F CFA (46.3\$ USD) per night. The air-conditioned single room is rented at 15,000 F CFA (27.7\$ USD) and $7500 \mathrm{~F}$ (13.8\$ USD) for the ventilated room. The condition of this hotel is rated as satisfactory.

*Pondori Hotel:

This hotel opened in Djenné Kanafa in 2011. It has 8 rooms and 12 beds. Three men work at this hotel which employs neither woman nor foreigner. The meal menu is $5000 \mathrm{~F}$ CFA (9.2\$ USD). The air-conditioned room is 20,000 F CFA (36.9\$ USD) and 10,000 F CFA (18.4\$ USD) for the ventilated one. Its condition is considered satisfactory.

${ }^{\star}$ Hotel Village des Amis: 
Table 3. Functional hotels in Djenné.

\begin{tabular}{|c|c|c|c|c|c|c|}
\hline \multirow{2}{*}{ Establishments } & \multicolumn{2}{|c|}{ Capacities } & \multicolumn{2}{|c|}{ Jobs } & \multirow{2}{*}{ Menu } & \multirow{2}{*}{ Prices } \\
\hline & Rooms & Beds & Men & Women & & \\
\hline $\begin{array}{l}\text { Campement } \\
\text { Houber Hotel }\end{array}$ & 48 & 60 & 5 & 0 & 2.000 F CFA & $\begin{array}{c}25,000 \mathrm{~F} \text { (Suite) } \\
15,000 \mathrm{~F} \text { (AC) } \\
10,000 \mathrm{~F} \text { (fan) }\end{array}$ \\
\hline Hotel Pondori & 8 & 12 & 3 & 0 & 5000 F CFA & $\begin{array}{l}20,000 \mathrm{~F}(\mathrm{AC}) \\
10,000 \mathrm{~F}(\mathrm{fan})\end{array}$ \\
\hline $\begin{array}{l}\text { Hotel Village } \\
\text { des Amis }\end{array}$ & 16 & 19 & 2 & 2 & $\begin{array}{c}1250 \text { à } \\
3000 \text { F CFA }\end{array}$ & 3000 F CFA \\
\hline Hotel Almansour & 10 & 14 & 3 & 3 & $\begin{array}{c}2000 \text { à } \\
7000 \text { F CFA }\end{array}$ & $\begin{array}{c}30,000 \mathrm{~F} \\
25,000 \mathrm{~F}(\mathrm{AC}) \\
17,500 \mathrm{~F} \text { (fan) }\end{array}$ \\
\hline $\begin{array}{l}\text { Hotel } \\
\text { Résidence Tapama }\end{array}$ & 13 & 24 & 1 & 2 & 2500 F CFA & 5000 F CFA \\
\hline Hotel Maafir & 16 & 20 & 1 & 0 & 2500 F CFA & $\begin{array}{l}23,000 \text { F CFA (AC) } \\
18,000 \text { F CFA (fan) }\end{array}$ \\
\hline
\end{tabular}

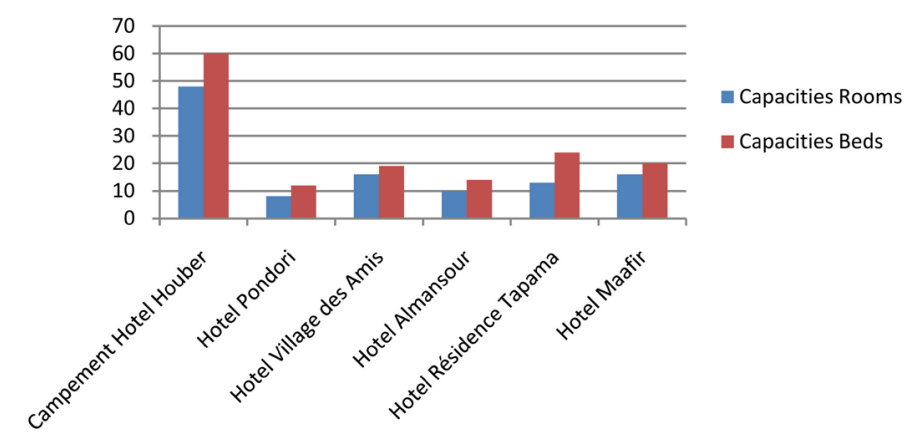

Source: Regional directorate of tourism and hospitality of Mopti.

Located in Djenné Sanouna, Hotel Village des Amis officially opened in 2010. It is a hotel with 16 rooms and 19 beds. Two men and two women, both of Malian nationality, work there. The price of food varies from 1250 to 3000 F CFA ( 2.3 to $5.5 \$$ USD). The room is $3000 \mathrm{~F} \mathrm{CFA} \mathrm{(5.5 \$} \mathrm{USD)} \mathrm{per} \mathrm{night.} \mathrm{The} \mathrm{condition}$ of the hotel is rated as acceptable.

${ }^{*}$ Almassour Hotel:

Located in Djenné Dotemé, this hotel, which began in 2011, has 6 rooms for 14 beds. Three men and 3 women work there, no foreigners. The restaurant menu varies from 2000 to 7000 F CFA (3.7 to $12.9 \$$ USD). Some air-conditioned rooms are at 30,000 F CFA (55.4\$ USD) per night, others at 25,000 F CFA (46.2\$ USD). The ventilated room is $17,500 \mathrm{~F}$ CFA ( $32.3 \$$ USD). The condition of this hotel is rated as satisfactory.

*Hotel Residence Tapama:

Named after the martyr Tapama (virgin maiden), this establishment is located in Djenné Kanafa and has 13 rooms for 24 beds. He employs 2 women and a man, no stranger. The restaurant menu is $2500 \mathrm{~F} \mathrm{CFA} \mathrm{(4.6 \$} \mathrm{USD).} \mathrm{The} \mathrm{room} \mathrm{is}$ 
rented at $5000 \mathrm{~F} \mathrm{CFA} \mathrm{(9.2 \$} \mathrm{USD)} \mathrm{per} \mathrm{night.} \mathrm{This} \mathrm{hotel} \mathrm{is} \mathrm{rated} \mathrm{as} \mathrm{good.}$

${ }^{\star}$ Maafir Hotel:

It opened in February 2001. Located in Djenné Kanafa, it has 16 rooms for 20 beds. The hotel has only one employee. The menu is 2500 F CFA (4.6\$ USD). The ventilated room is at 18,000 F CFA (33.2\$ USD) per night, 23,000 F CFA (42.5\$ USD) for the air-conditioned one. This hotel is rated as acceptable.

The economic, social and cultural development of urban systems presupposes the presence of a solid and diversified infrastructure network (Barramou, Mansouri, \& Addou, 2020). The closed establishments are Hotel Djenné-Djeno, Hotel Dar salam, Hotel Kita kourou, the Sirabougou camp, and the Frederic Begeber reception center.

After the closure of these 5 establishments, the 6 functional hotels currently offer 149 places (beds) divided between 111 rooms. Three of the 6 hotels are rated in fair condition, 2 are fair and one is rated good. These 6 hotels employ 15 men and 7 women, all of Malian nationality. The cost of living is acceptable in the small town of Djenné which is located in the interior of the country. The average cost of catering is around $3660 \mathrm{~F} \mathrm{CFA} \mathrm{(6.7 \$} \mathrm{USD)} \mathrm{in} \mathrm{hotel} \mathrm{structures.} \mathrm{The} \mathrm{most} \mathrm{expensive}$ rooms vary between 25,000 and $30,000 \mathrm{~F} \mathrm{CFA} \mathrm{(46.2} \mathrm{to} 55.4 \$$ USD). The cheapest is at $3000 \mathrm{~F} \mathrm{CFA} \mathrm{(5.5 \$} \mathrm{USD).} \mathrm{These} \mathrm{hotel} \mathrm{structures} \mathrm{most} \mathrm{often} \mathrm{receive} \mathrm{visitors} \mathrm{from}$ other countries and some missionaries from government or non-government organizations. In Malian culture, national visitors are most often received by the family of a relative or friend living in the locality concerned.

Urban achievements have effects on the lives of populations (Monioudi-Gavala, 2019). During our interviews, hotel managers say that they have received no help in this crisis which has already lasted 8 years. There are difficulties in meeting hotel charges such as employee salaries, annual maintenance of muddy buildings, and other bills. It was under these difficult conditions that many employees were sent out of work. Some of them try to convert to farming or fishing with varying degrees of success. Others choose to emigrate. Among the social consequences linked to these job losses, we have some divorces.

The architectural heritage is the basis of the tourist vocation of Djenné. Earthen houses are suitable for populations for climatic, economic, and cultural reasons. The city has many infrastructures such as the Grand Mosque and accommodation structures that promote tourism and contribute to the local economic life. The Malian government has adopted a whole legal arsenal (laws and other texts) to promote architectural conservation. International partners took part in the heritage restoration work. The population attached to its cultural values is one of the main assets of this conservation.

\section{The Current Crisis and Its Effects on Djenné and Its Architectural Heritage}

The classification of a site on the World Heritage List must extend to all the cultural values which have produced the material framework that it is desired to protect. The issue of development should be taken into account. 
"Too often, recourse to the precepts of sustainable development and heritage rings false in the face of the reality of local deprivation" (Ouallet, 2007: p. 93). In a community where survival is the key word, we cannot calmly consider conservation (Laureau, 2013: p. 37).

Climate change, poverty, the strong pressure on natural resources, wars, and terrorism are real threats to cultural heritage. The earthen architectural heritage is fully exposed to these problems. In 2001, the world sadly witnessed the blasting of the 7th century Bamiyan statutes. This heritage then included the tallest Buddha statue in the world. Syrian UNESCO World Heritage sites have been destroyed or damaged by gunfire, bombardments, illegal occupations, and looting during the civil war since 2011. In 2012, the mausoleums of Timbuktu were broken and desecrated by terrorists in Mali.

\subsection{The Abandonment of Djenné Destination by Tourists}

Table 4 shows us the evolution of the number of visitors who arrived in Djenné from 2007 to 2019. We can divide the table into 02 parts.

From 2007 to 2011, there were 13,794 arrivals in Djenné. The number of visitors has always exceeded 1000 people with the maximum in 2009 (4732 people)

Table 4. Statistics of tourist visits to Djenné from 2007 to 2019.

\begin{tabular}{|c|c|c|}
\hline Years & Number of visitors & Overnight stays \\
\hline 2007 & 1722 & 2059 \\
\hline 2008 & 1878 & 2226 \\
\hline 2009 & 4732 & 5782 \\
\hline 2010 & 3649 & 4446 \\
\hline 2011 & 1813 & 2188 \\
\hline 2012 & 341 & 451 \\
\hline 2013 & 24 & 28 \\
\hline 2014 & 299 & 340 \\
\hline 2015 & 111 & 123 \\
\hline 2016 & 0 & 0 \\
\hline 2017 & 118 & 209 \\
\hline 2018 & 218 & 344 \\
\hline 2019 & 215 & 254 \\
\hline
\end{tabular}

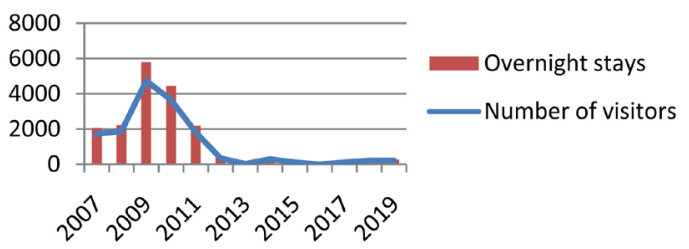

Source: Regional directorate of tourism and hospitality of Mopti. 
followed by 2010 (3649 people). The number of overnight stays is equal to 16,701 . This first period was marked by security and political stability in Mali, conditions which allowed the normal development of tourist activity in the destination of the architectural heritage of Djenné and throughout the country.

The second part of the figures contained in the table relates to the period 2012-2019. The total number of visitors is 1326 visitors for the 08 years, an average of 166 visitors per year. The year 2012 got its peak with 341 visitors. The length of stays also dropped considerably during this period, 1749 overnight stays for 8-year-olds. What happened?

The year 2012 marked a turning point in the political evolution of Mali. Indeed, it was from January 2012 that the Malian state was attacked by the armed rebellion of the National Movement for the Liberation of Azaouad (MNLA) in collaboration with the jihadists. Since these unfortunate events that led to the coup d'état of March 22, 2012, the Malian government has lost control of the north and center (to which Djenné belongs) of the country to armed groups comprising, on the one hand, the Tuareg separatists and on the other hand their "jihadist cousins". If the former demanded the partition of the country, the latter carried a project for the application of Islamic law throughout Mali and even beyond. Once the Malian government (which was their common enemy) defeated, the two tendencies had to face up to the differences linked to the implementation of their respective projects. This situation escalated. Violent clashes followed. Thus, the Islamist groups, especially the Movement for Uniqueness and Jihad in West Africa (MUJAO) and AQIM won over the Tuareg separatists grouped within the National Movement for the Liberation of Azawad (MNLA). Islamist groups then began to reign as absolute masters while making a name for themselves in the application of the only so-called Islamic law through the prohibition of Western values and the administration of extreme abuse to people accused of adultery or theft. The Jihadists wanted to go further by advancing south to extend their control to the whole country. The Malian government then requested and obtained an intervention from France which succeeded in dispersing them in January 2013. The French continued to hunt them down in their various lairs. An African-led International Support Mission in Mali (MISMA) is authorized by the United Nations Security Council in its Resolution 2085 dated December 20, 2012. It is deployed for an initial period of one year. Resolution 2085 provides for MISMA to help "rebuild the capacity of the Malian armed forces" to allow the authorities to retake control of the territory while preserving the civilian population. MISMA aims to support the Malian army to dislodge the Islamist groups that have driven out the independence rebels.

MISMA is relayed by the United Nations Multidimensional Integrated Stabilization Mission in Mali (MINUSMA) from July 1, 2013. The resulting insecurity is the main cause of the decline in the tourist activity for the architectural heritage of Djenné. Westerners, the military, and other representatives of the Malian state are targeted. In the report of the National Institute of Statistics, among the 
tourists who visited Mali in 2016, there were 44,710 French, 2758 Spaniards, 1291 Germans, 1256 Italians, and 1151 Dutch.

Central Mali (to which Djenné belongs) is currently the most dangerous with insecurity and violence. This region is the field of $40 \%$ of the country's attacks.

Between January and August 2018, 500 civilian casualties were reported. Insecurity manifests itself in assassinations, attacks, and hostage-taking. Villages are burned (160 dead in Ogossagou on March 23, 2019). More than 15,000 people have fled the violence.

The jihadists raging in central Mali are those of the Katiba of Macina led by the Muslim preacher named Amadou Koufa, a member of the Al Qaïda nebula in the Islamic Maghreb (AQIM). It forms the Support Group for Islam and Muslims (GSIM) under the command of Iyad Ag Ghali. Faced with these jihadists, we have the Malian armed forces supported by foreign ones (France, MINUSMA) which carry out anti-terrorist operations. Besides, there are also the local community militias who call themselves self-defense groups of their respective communities. The proliferation of self-defense groups that are beyond government control explains the inter-communal violence that allegedly left at least 287 dead between April and June 2018 according to a report by the United Nations Secretary-General dated September 25, 2018 (S/2018/866, September 25, 2018).

The abandonment of the Djenné destination is confirmed by the authorities and hoteliers. Here are the words of Mr. DEMBELE, 2nd deputy mayor: "As tourists no longer come, we even identified the agent who was in charge of collecting the tourist tax. We gave him other tasks."

As we wrote above, 5 hotel establishments have already closed in Djenné. The employees then find themselves directly in unemployment. Also, the hotels currently open are in difficulty. When questioned, the managers of these hotels told us about their difficulties in covering their multiple charges and are constantly reducing their staff. The manager of the Hotel Houber told about dozens of employees already fired. These heads of families will swell the lot of the unemployed, who, after difficulties in retraining, can become easy prey for criminal organizations. Unemployment is a source of insecurity.

\subsection{Tourism Guides and Their Problems}

To develop and promote its international tourism, Mali adopted Law No. 03-040 of December 30, 2003, governing the professions of travel and tour operators and tourist guides and its implementing decrees. The adoption of these texts allowed, in 2018, the creation of 561 travel agencies, the certification of 522 tourist guides (161 national and 361 local).

Tourist guidance is one of the sectors most affected by the consequences of security problems in central Mali in general and especially in Djenné. This profession that made rain and shine is experiencing unprecedented hardship.

Before the crisis, tourist guiding was one of the richest activities. Here are the 
testimonies of the Head of the Cultural Mission whom we interviewed: "some guides have become very wealthy and are among the largest traders in the city". The Regional Directorate of Tourism and Hospitality has given us a list of 25 people as professional guides of Djenné. Note that impostors are also evolving in the sector. In the tourist guide jargon, there is the guide, the guitar and the handlebars. The guide is a professional recognized by the government, having a professional card (Interministerial decree $n^{\circ}$ 05-1512/MAT-MSIPC setting the characteristics and methods of granting the professional card and the badge of a tourist guide) and doing his job well legally. The guitar only tells lies to distract visitors by accompanying them. Finally, the handlebars are not qualified. The latter, which offers its services at a low price, does not have the necessary skills to exercise this regulated function (Decree $n^{\circ} 04$ 123/P-RM of April 21, 2004 setting the terms and conditions for the exercise of the profession of tourist guide) government and then operates illegally.

We were able to interview 10 of the 25 professional guides. Table 5 shows us their distribution by age group. $50 \%$ of them are young and under 40 years old. The 40 to 50 age group represents $40 \%$. Finally, a proportion of $10 \%$ has already exceeded 50 years. Overall, we have a proportion of $50 \%$ of young people and a proportion of $50 \%$ of adults and seniors. Faced with the current crisis, retraining in another activity is the only alternative. This alternative is possible for young people under 40 years old. But again, it is very complicated. However, our surveys revealed that $70 \%$ of our sample practiced tourist guiding as their main activity. Only $30 \%$ of them performed this function alongside other income-generating activities. $80 \%$ of these guides told us that they had not received any support to retrain in other activities. The $20 \%$ admitted having benefited from the assistance of the NGO “Actif" to embark on other activities. On July 17, 2015, Radio France Internationale published this: "like in the north of the country, the tourism sector is at half-mast in central Mali, because of security problems. This generates a loss of income for the government and very directly weakens tourist

Table 5. Breakdown by age group of the tourist guides interviewed.

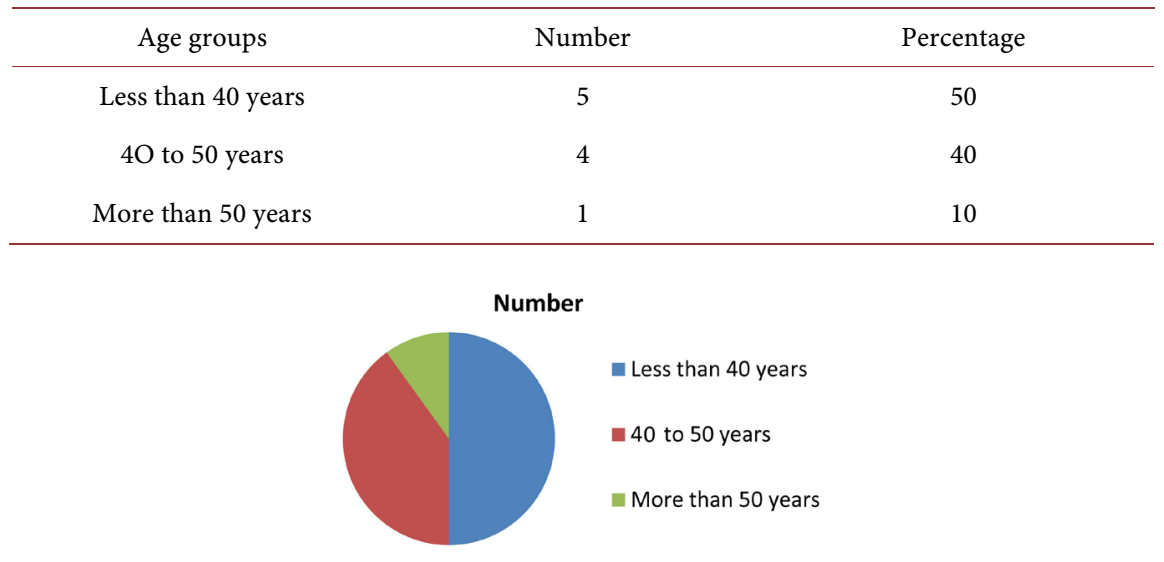

Source: Our own surveys among the inhabitants of Djenné, November 2020. 
guides. The latter, who accompanied tourists on their travels, are now helpless. "Further on, there was this testimony from Djibril KASSOGUE, a tourist guide who became a farmer:" There, we start to cultivate millet in the village, beans, and cereals ". These various passages published by the RFI clearly illustrate the general malaise in central Mali, including Djenné, and especially the tourism situation.

Following the law (Law n ${ }^{\circ}$ 04-038 of August 5, 2004 relating to associations) and to better supervise tourist guidance, there is an association of guides of Djenné. This association should be the center where efforts are harmonized to defend the interests of these professionals. It should be the interlocutor of government and development partners. Unfortunately, $50 \%$ of the guides questioned admitted that they were not members of this organization. We sought to find out more.

We can see from Table 6, 40\% of guides non-members denounce the mismanagement of this organization. $20 \%$ think it is less in seriousness. The same proportion thinks it is unnecessary. Finally, $20 \%$ of these guides say they do not have time for the association. All of these answers converge on the same thing. There is a dysfunction of the association that fails to convince those concerned. To verify these complaints, we also questioned members about what the association brings them. $80 \%$ of them answered that this did not help them. The $20 \%$ recognized the contribution of the association in the training of guides. The training is not negligible. However, the association should go further to meet the aspirations of professionals in the sector. It must initiate programs and mobilize funds to alleviate the suffering of the guides in this period. It must also fight effectively against the illegal exercise of the profession. All this would be possible if the tourism guides agreed to join it and impose effective leadership.

Table 6. Guides' responses to the reasons for their non-membership of the association.

\begin{tabular}{|c|c|c|}
\hline Reasons & Number & Percentage \\
\hline Mismanagement & 2 & $40 \%$ \\
\hline Serious lack & 1 & $20 \%$ \\
\hline Uselessness & 1 & $20 \%$ \\
\hline \multirow[t]{6}{*}{ Lack of time } & 1 & $20 \%$ \\
\hline & \multicolumn{2}{|l|}{ number } \\
\hline & \multicolumn{2}{|c|}{ Mismanagement } \\
\hline & \multicolumn{2}{|c|}{ Serious lack } \\
\hline & \multicolumn{2}{|c|}{ uselessness } \\
\hline & \multicolumn{2}{|c|}{ Lack of time } \\
\hline
\end{tabular}

Source: Our own surveys among the inhabitants of Djenné, November 2020. 


\subsection{The Situation in Some Other Socio-Professional Sectors in Djenné}

Table 7 gives us the distribution of our sample by socio-professional category. This breakdown is about the 50 people we interviewed. Traders represent $40 \%$ of this sample. Petty trading was one of Djenné's flagship activities due to the masses of visitors flocking to the city. Also, doing business in this sector does not require years of apprenticeship. This sector is an opportunity for reconversion.

Hairdressers represent $8 \%$ of our sample. In general, in Mali, the practice of this activity does not require formal training or large means. This activity generally benefits from a loyal local clientele.

Craftsmen represent $20 \%$ of our sample. Handicrafts are a sector that directly enjoys the benefits of tourism. Visitors generally buy jewelry, shoes, bags, and many other art objects to make souvenirs. Handicrafts flourish in tourist areas.

Four percent $(4 \%)$ of our sample are dressmakers. Their market is aimed at both local customers and visitors interested in traditional local outfits.

Breeders represent $12 \%$ of our sample. This traditional breeding mainly concerns cattle, sheep, and goats. Djenné, like other parts of the Sahel, is an important livestock region. The animals are sold on the regional and national markets. Breeding is part of the culture of the Sahelian populations. The Fulani, who are also present in Djenné, is reputed to be excellent breeders. Most often, these herders practice transhumance because of the long dry season which deprives them of grazing in the surroundings.

Table 7. Some socio-professional groups affected by the crisis in Djenné.

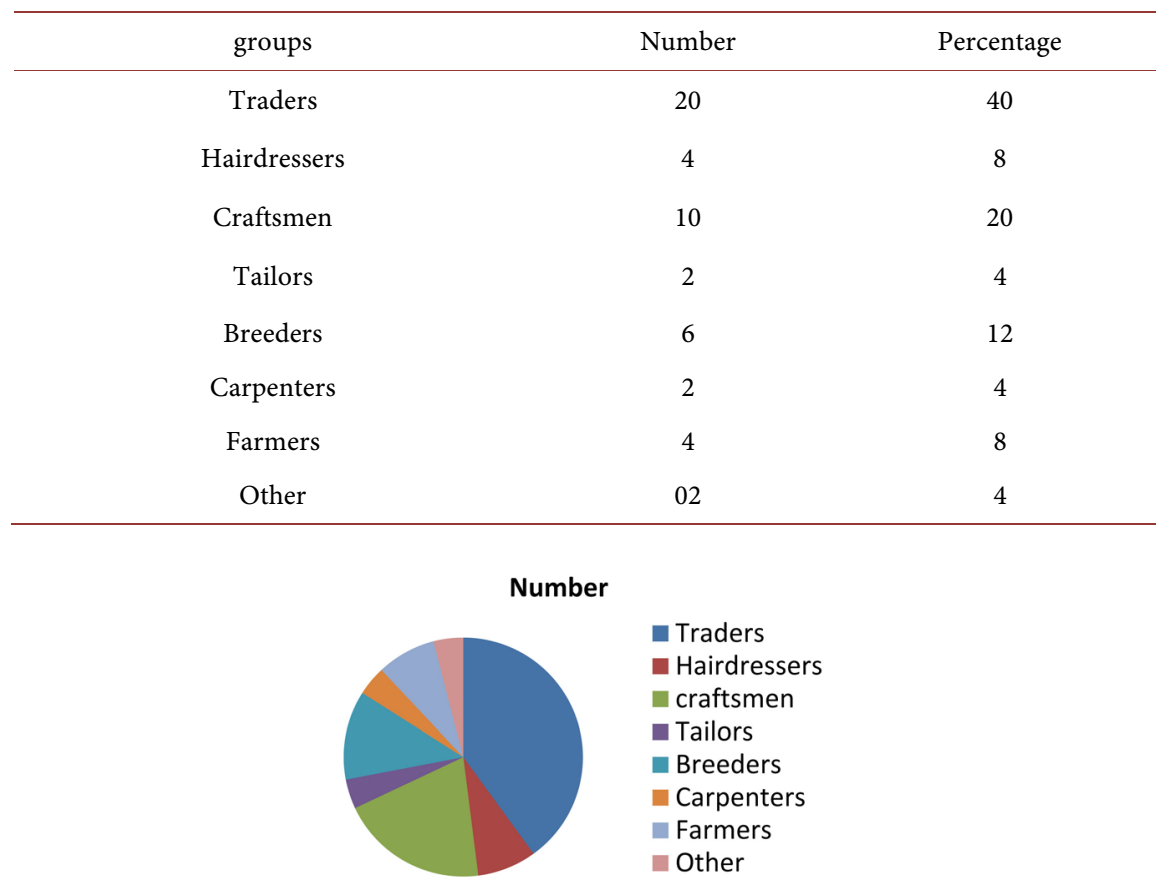

Source: Our own surveys among the inhabitants of Djenné, November 2020. 
Our sample also included $4 \%$ carpenters. They make furniture and are involved in some tasks related to the construction of houses like doors and windows. If they are not directly concerned by the tourist activity, they feel, like the rest of the population, this crisis weakens the purchasing power.

Farmers represent $8 \%$ of our sample. Despite certain difficulties, notably the drought of the 1950s and 1970s, agriculture remains an important activity in Djenné thanks to the efforts of rural development operations launched by the government and which have brought about an improvement in agricultural techniques. Djenné produces sorghum, millet, peanuts, rice (in the floodplains), cotton, etc.

Finally, we have classified the marabouts in the "other" section. You have to know Malian society to see the definition of a marabout in socio-professional activities. In popular Malian beliefs, marabouts occupy an extraordinary place. It is indeed a lucrative activity that nourishes her man and which can go far beyond to make its practitioners truly privileged in society. For all the problems of life, Malians have recourse to the prayers and mystical services of marabouts for money. The city of Djenné which is renowned for its deep Islamic culture is also the area par excellence of marabout. Not all visitors to Djenné are tourists. There are also politicians, government workers, traders, businessmen, etc. those who hope to find there the appropriate answers to their respective needs thanks to the occult sciences of the marabouts. Besides the marabouts who practice these occult sciences, there are also other people working exclusively in the field of religion including imams, muezzins, and sometimes preachers. They are often maintained by the mosque and the faithful. Also, these religious leaders manage to make money during social ceremonies such as baptisms and funerals for which they provide their Quran reading and preaching services to the families concerned. This phenomenon is present everywhere in Mali.

Some activities are not directly concerned with tourism. But it is the entire population that is feeling the effects of the crisis because of the interdependent nature of the activities.

Table 8 gives us the main difficulties mentioned by the people questioned as well as the proportion of people complaining about each of these difficulties. The percentages contained in the table cannot be combined for the simple reason that the same individual can express different difficulties at the same time.

Thus, the decline in clientele was mentioned by $20 \%$ of our sample. This is inherent in the reduction of movements in the area as well as its domino effects on all income-generating activities.

Difficulties in accessing credit are reported by $30 \%$ of our contacts. The Network of Authorized Village Savings and Credit Banks (CVECA) is a decentralized financial system that covers a large part of Malian territory, including Djenné. These funds mobilize savings and facilitate access to local credit. The activity of these funds is linked to the state of economic life which determines the possibility of savings and the solvency of debtors. The current socio-economic 
Table 8. Opinions of the people questioned on the consequences of the crisis.

\begin{tabular}{ccc}
\hline Conseqences & Number & Percentage \\
\hline Decline in clientele & 10 & 20 \\
Difficulties in accessing credit & 15 & 30 \\
Weakening purchasing power & 30 & 60 \\
Theft and robberies & 10 & 20 \\
Others & 2 & 4 \\
\hline
\end{tabular}

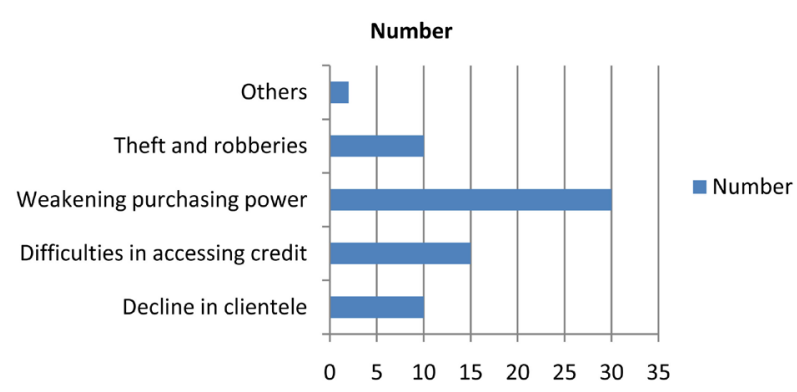

Source: Our own surveys among the inhabitants of Djenné, November 2020.

crisis, which is not sparing microfinance structures, then justifies the difficulties in accessing credit.

Purchasing power is an economic concept that is used to measure the number of goods and services that an income provides. It can be assessed at the level of a household, region, country, etc. it is an indicator of economic health and development. So $60 \%$ of the people in our sample naturally recognize the decline in purchasing power as one of the big problems today.

All the difficulties mentioned undoubtedly lead to poverty and unemployment which in turn create favorable conditions for thefts, robberies, and other forms of banditry. This is unsurprisingly evident from the opinion of $20 \%$ of our sample. This social crime is compounded by other consequences of the war, including the illegal circulation of weapons, lack of supervision, and the closure of schools. Breeders and traders are the most exposed to these thefts and robberies.

Another consequence of the insecurity on the conservation of the architectural heritage of an Islamic character is the threat linked to the evolution of the conception of Islam according to its different tendencies. The armed groups are close to the Sunni tendency which would prohibit certain worship practices associated with the conservation of the building. Thus, in Timbuktu, in 2012, there was the desecration of cultural property of an Islamic nature. The security issue should be taken into account in the management of the conservation of the cultural property in countries at war.

Ultimately, we could see that the security crisis has plunged Djenné into chaos. The visitors abandoned Djenné. Due to the interdependent nature of its sectors, all socio-economic life has been tested by the effects of the crisis. The local population is hit by problems such as poverty, unemployment, and inse- 
curity. This situation seriously threatens the heritage conservation and urban development of Djenné.

\section{Conclusion}

Djenne is undoubtedly one of the greatest cultural assets in Mali and the world. This city contains important resources that teach the past of the region and the world, especially the urban phenomenon. The inclusion of Djenné as a world heritage site by UNESCO has increased the need to conserve this rich cultural asset, the economic benefits of which, through tourism, partly explain the relative local prosperity. The current insecurity which has reduced tourism and the cost of maintenance that residents are starting to complain about are threats to the architectural conservation of Djenné.

\section{Conflicts of Interest}

The authors declare no conflicts of interest regarding the publication of this paper.

\section{References}

Barramou, F., Mansouri, K., \& Addou, M. (2020). Toward a Multi-Dimensional Ontology Model for Urban Planning. Journal of Geographic Information System, 12, 697-715. https://doi.org/10.4236/jgis.2020.126040

Brunet-Jailly, J., Charmes, J., \& Konaté, D. (2014). Le Mali Contemporain. IRD Éditions, Marseille, Hors Collection. https://doi.org/10.4000/books.irdeditions.21053

Cissé, L. (2008). Constructions en terre au Mali: Dynamiques sociales et culturelles d'une tradition ancestrale de construction. $L, 844,6-12$.

Grignolo, R. (2018). An Encyclopedic Approach to the Conservation of $20^{\text {th }}$-Century Architecture. Built Heritage, 2, 93-102. https://doi.org/10.1186/BF03545696

Gulzar, S., \& Burg, J. P. (2018). Preliminary Investigation of Late Mughal Period Wall Paintings from Historic Monuments of Begumpura, Lahore. Frontiers of Architectural Research, 7, 465-472. https://doi.org/10.1016/j.foar.2018.08.001

Holder, G. (2012). Djenné, «la ville aux 313 saints». Convocation des savoirs, «lutte des classements» et production d'une ville sainte au Mali. Cahiers d'Études Africaines, 52, 741-765. https://doi.org/10.4000/etudesafricaines.17152

Joy, C. L. (2016). The Politics of Heritage Management in Mali: From UNESCO to Djenné. New York: Routledge. https://doi.org/10.4324/9781315417530

Laureau, V. (2013). La ville en terre au Mali. Le chantier comme patrimoine. Cybergeo: European Journal of Geography. https://doi.org/10.4000/cybergeo.25907

Marchand, T. H. J. (2009). The Masons of Djenné. Bloomington, IN: Indiana University Press.

Monioudi-Gavala, D. (2019). Rebuilding Greece, 1830-1920. Ambitions and Realities. Advances in Historical Studies, 8, 199-214. https://doi.org/10.4236/ahs.2019.85015

Namangaya, A., \& Mushi, D. (2019). Actors' Influences on Land Use Planning Decisions in Small Towns: The Case of Geita, Gairo and Kibiti Towns in Tanzania. Open Journal of Social Sciences, 7, 172-190. https://doi.org/10.4236/jss.2019.77016

National Directorate of Tourism and Hotels (2020). Collection of Texts Governing Tour- 
ism in the Republic of Mali. Bamako, Mali.

National Institute of Statistics (2018). Mali in Figures 2012-2016. Bamako, Mali.

Ouallet, A. (2007). Heritage and Time Scales in the World's Heritage African Cities: Case Studies in Mali and Ethiopia. Espace Populations Societies, 2, 317.

van Beek, W. E., Lemineur, P., \& Walther, O. (2007). Tourisme et patrimoine au Mali: Destruction des valeurs anciennes ou valorisation concertée? Geographica Helvetica, 62, 249-258. https://doi.org/10.5194/gh-62-249-2007

Yamoussa, F., \& Joffroy, T. (2010). Villes anciennes de Djenné(36 p). CRAterre-ENSAG. 